\title{
SUSTAINABLE SOCIAL DEVELOPMENT, ECONOMIC GROWTH AND TECHNOLOGICAL BREAKTHROUGHS: CREATIVITY AND CREATIVE CHANGE
}

\author{
Borisas MELNIKAS* \\ Vilnius Gediminas Technical University, Faculty of Business Management, \\ Department of Economics Engineering, Sauletekio al. 11, LT-0223 Vilnius, Lithuania
}

Received 16 May 2019; accepted 24 October 2019

\begin{abstract}
This theoretical article is intended for complex analysis of complicated phenomena and processes of the promotion of creativity and creative changes in the main areas of the contemporary social and economic life, as well as for the current and most important issues of sustainability, social development, economic growth and technological breakthroughs.

Purpose - to prepare, disseminate and implement the new concept of the sustainable social development, economic growth, innovations and technological breakthroughs, the essence of which is an integrated holistic approach to harmonization of various development processes and the use of specific managerial tools and instruments based on the ideas of creativity and creative changes. Research methodology - systematic analysis and synthesis of various scientific ideas and approaches, formulation and analysis of new insights.

Findings - a new concept of the promotion of creativity and creative changes is prepared. This concept provides an integrated approach to the solution of the problems of social development, economic growth, innovation activities, technological progress and breakthroughs, as well as of the application of the specific managerial tools and instruments based on the ideas of creativity and creative changes. Implementation of this concept in the practice of the social and economic activities, research and academic studies creates various preconditions for anticipation and realization of new opportunities for social and economic development and technological breakthroughs under contemporary conditions of globalization, European integration and the creation of knowledgebased society.

Research limitations - the proposed concept is limited to the cases of the research on general tendencies and the development processes of the society, as well as to the cases of the macroeconomic analysis and preparation of the strategic decisions for social, economic, political and technological development.

Originality/Value - the new insights and perspective ideas provided for the priorities of the various social sciences and humanities, particularly - sociology, economics and management science, and of the application of the specific management tools, are described and analyzed. Orientation to these insights and ideas highlights new significant trends in the scientific research.
\end{abstract}

Keywords: creativity, economic growth, innovation, management, scientific research, social development, sustainability, technological advance and breakthroughs.

${ }^{\star}$ Corresponding author. E-mail: borisas.melnikas@vgtu.lt 


\section{Introduction}

The problems and processes of the creative changes (CCs) and sustainable social development $(S D)$, economic growth (EG) and technological breakthroughs (TBs) could be appreciated as a new and a very significant field in the contemporary social sciences and humanities (SSHs), as well as a very important area of various practical activities. This statement can be justified by the fact that the processes of the promotion of creativity (PC) and CCs, of the sustainable $S D, E G$ and targeted $T B s$, as a whole, should be perceived as essentially constituting all the main preconditions for the full realization of all the major expectations of modern society.

It is important to emphasize that the processes of the PC and CCs, of the sustainable $S D$, $E G$, as well as the processes of TBs are inseparable from each other, they form a single entity. Under these circumstances, it is relevant to discuss and identify the essentials and key concepts and provisions of the scientific cognition (SC) and scientific research (SR) on these processes, as well as to define, explore and investigate those ideas, development tendencies and directions, that could be understood as of particular significant and promising.

The processes of the PC and CCs, sustainable SD, EG and TBs, as a whole, can be considered as a very complicated area of the SC and SR, as well as a particularly important field of practical activities. It is necessary to emphasize that the SC and SR, as well as a practical activities of this kind can be defined as a very complicated, important and significant, because the processes of the $P C$ and CCs, sustainable SD, EG and TBs, as a whole, always accumulates and reflects a number of exceptionally significant factors of the progress and of the intensive $\mathrm{SD}$ and economic development (ED), as well as a many quite contradictory circumstances, that are characteristic to the essential changes in the life of contemporary society (CSO).

It should be emphasized that the processes of the SD, EG and TBs are comprehensively and complexly investigated in many scientific works, including some of the author's previous works and publications (Melnikas, 2011, 2013, 2014, 2018). However, it should be noted that an appropriate attention to the interaction of these processes with the various circumstances of the CCs, and the processes of the PC and CCs, has not been addressed in previous research practice. This means that it is very important to integrate all interconnected processes of the SD, EG and TBs, as well as the processes of the PC and CCs, into a common area of holistic scientific knowledge and research.

Thus, a complex and holistic approach to the common field of the scientific cognition and research of all these processes of the SD, EG and TBs, as well as the processes of the PC and CCs is what distinguishes this approach from the other approaches discussed in earlier author's publications (Melnikas, 2011, 2013, 2014, 2018).

The different processes of the PC and CCs, of the sustainable SD, EG and TBs are not only rich in diversity, but they are interrelated with many quite contradictory relationships and dependencies. For example, the technological progress (TP) and the TBs are usually perceived as the most important factor of the SD and EG in general. It is also obvious that the different processes and manifestations of unsustainable development can be defined very often as the result of various TBs: the processes of TBs can lead to different disproportions in traditional and relatively well-established systems of SD, ED, technological development 
(TD) and ecological development (ECD), and such disproportions create preconditions for further unhealthy and unsustainable SD and EG.

It is important to emphasize that in real social and economic life (SEL) of modern society it is necessary to achieve a harmony and coherence between various SD and ED processes, as well as between various technological changes (TCs) and environmental transformations: various social changes (SCs) and economic changes (ECs) and TBs must be oriented towards the sustainability of the SD, EG and interaction with the environment.

It can be said that only those SCs and ECs and TBs can be considered as advanced and desirable, that do not violate the aspirations, norms of sustainability (NR) and requirements of the sustainability (RS) of the societal life, SD or EG and do not cause disproportions between the SD, ED, TD and ECD processes.

It goes without saying that all the processes of the sustainable SD, EG and TBs must have $a$ focus on creativity and CCs. By the way, it should be emphasized that all goals of sustainability (GS) and all needs of the sustainable development (SUD) can be realized only in the cases where the processes of the development and changes in their sense and logic are the creative.

It means that, on the one hand, it must be emphasized that the processes of the PC and CCs, of the sustainable SD, EG and TBs should be defined as the essential priorities for the development of modern society. On the other hand, various measures must be taken to ensure that the processes of the PC and CCs, of the sustainable SD, EG, TP and TBs should be actually geared towards sustainability and sustainable SD and EG.

It can be said that the practical activities and the SR on the processes of the PC and CCs, of the sustainable SD, EG and TBs must be oriented to the solution of the problems, the essence of which - the creation and application of the tools and instruments needed to ensure that all SCs, ECs and TCs and TBs should to guarantee the sustainability of the SD and EG and the proportionality of the SCs, ECs, TCs, ecological changes (ECCs) and other changes.

So, the lack of the appropriate managerial tools and instruments needed to ensure that the SCs, ECs and TCs and TBs should to guarantee the sustainability and the proportionality of the SCs, ECs, TCs, ECCs and other changes, could be defined as a very serious scientific problem $(S C P)$ and practical problem (PP).

This problem can also be described in a somewhat different way - as the lack of the appropriate managerial tools and instruments needed to harmonize the processes of the SCs, ECs and TCs and TBs, as well as to guarantee the sustainability in all important sectors of the SEL of the society.

Obviously, analyzing and solving this problem can be seen as an important priority of the modern SSHs.

There are various possibilities to solve this problem. This means that the various theoretical approaches (TAs) to this problem can be discussed and implemented into the practice of the SR on various circumstances of sustainability and on the processes of the sustainable SD, EG and TBs.

One of the possible TAs to solving this problem is based on the idea that the orientations towards the sustainability and sustainable SD, EG and TBs can be guaranteed through the use and application of the instruments and tools aimed at promoting and supporting creativity and CCs. 
This means that the creation and use of the managerial tools and instruments that realize the ideas and goals of the PC and CCs can be seen as a crucial priority for overall research on sustainability, SD, EG and TBs.

This statement can be considered as sufficiently justified because: a) the processes of the PC and CCs are always an integral and indispensable part (IIP) of any activities aimed at the $\mathrm{SD}, \mathrm{EG}, \mathrm{TP}$ and TBs, as well as at the sustainability in general; b) the abilities to understand and realize the needs of the purposeful PC and support of the creativity (SUC) and CCs can be defined as the essential prerequisites for the achieving the most important aims, GS and objectives of sustainability (OS) and harmony and coherence between the various processes of $S D, E G, T P$ and TBs.

These insights make it possible to formulate a hypothesis that the creation and use of the managerial tools and instruments that realize the ideas of the targeted and purposeful PC and SUC and CCs can be seen as a priority assumption and condition for the achieving of the GS and needs of sustainability (NS) and harmony between the processes of the SD, EG, TP and TBs.

This publication is intended to reveal the essence of the problems of compatibility and harmony between the processes of the SD, EG, TP, various TBs and the processes of activation of creativity and CCs in the all spheres of SEL, as well as to highlight the possibilities for practical implementation of the ideas and theoretical models of the effective and purposeful PC and SUC and CCs.

The subject (object) of the SR described in this publication can be defined in two ways: a) as the processes of the sustainable SD, EG and technological TBs, oriented towards the NS and challenges of sustainability (CHS) and creativity; b) as the possibilities and needs to use and apply the managerial tools and instruments for the effective and purposeful PC and SUC and CCs.

Tasks of the research described in this publication:

- to explore the role and importance of the processes of the contemporary sustainable $\mathrm{SD}, \mathrm{EG}$ and TBs, to highlight the needs and opportunities of the harmonization of these processes, particularly - in the context of contemporary challenges and the needs to activate a creativity and various CCs in the all spheres of SEL;

- to determine the main priorities of the effective and purposeful PC and SUC and CCs;

- to describe the role and importance of the creation and use of the managerial tools and instruments that realize the ideas and goals of the effective and purposeful PC and SUC and CCs, to highlight the needs and opportunities to apply these tools and instruments to harmonize the processes of sustainable SD, EG and TBs, as well as to guarantee the orientations of various innovation activities towards priorities of sustainability.

Methodology of the research is based on the traditional approaches to theoretical research (TR) and SC. Various ideas of the complexity of SC, of the analysis of quantitative changes and qualitative changes (QCs), as well as of the use of different methods and models of investigation and complex analysis of the processes of SD and ED are being implemented in the course of the research.

The results of the $S R$ are presented in this publication. The scientific novelty of these results can be described as follows: the new insights and analytical materials reflects some new ideas that can be used in the academic studies and SR on the processes of the PC, on the pro- 
cesses of sustainable SD, EG, innovation activities and of the acceleration of the social and TP and TBs. The practical value is that the results of the research can be used as the theoretical basis for the creation and further development of various support systems needed to activate the creativity and CCs, as well as for the acceleration of the SD, EG and innovation activities, TP and TBs, particularly - in the context of the contemporary challenges (CONCs) and NS.

The material published in this article reflects those new findings of the author's research and those new ideas from the author that extend the results of the previous research and supplements the statements of previous author's publications.

\section{Creativity, creative changes, the sustainable social development, economic growth, innovations and technological breakthroughs: contemporary challenges and the needs to realize a holistic approach}

The changes and breakthroughs in the all spheres of the life of humankind and its development, the origins, phenomena and mechanisms of these changes and breakthroughs can be perceived as the most important priority of the SC and knowledge about the world and nature (Harari, 2015). In turn, almost all changes and breakthroughs tend to have imbalances and differences in pace and scale, often characterized by a variety of inequalities and of the lack of mutual harmony. This means that such changes and breakthroughs can always lead to the destabilization of various systems and structures and to the loss of sustainability (LS) in different forms. Thus, various changes and breakthroughs, that may be characterized by inequality and by the lack of harmony, must necessarily be explored and investigated in the context of the CHS and problems of sustainability (PRS).

This statement is fully valid in all cases where changes and breakthroughs in the various areas of SEL and of the scientific progress (SP) and TP are examined and investigated. This statement is particularly relevant in the cases where TP and innovation processes, TBs, SD and EG are explored: in such cases, there is a lack of proportionality, equivalence and harmony very often, as well as there is a situation very often where ongoing changes and breakthroughs lead to the LS.

Among other things, these circumstances need to be taken very seriously, especially when it comes to exploring the processes of SD, EG and TBs, as well as when it comes to looking for opportunities to guarantee the sustainability and stability in different areas of the SEL of the society.

It must be emphasized that the processes of the SD, EG, TP, innovation and TBs are a key factor for the modernization and development of the society in general. It goes without saying that these processes should to be sustainable: it means that only those processes and changes can be considered as advanced and desirable, that do not violate the aspirations, NR and RS and do not cause disproportions between the SCs, ECs and ECCs and development processes (DPs) in general. It is obvious that the all these processes must be geared towards the goals of SUD and that the orientations and trajectories of these processes, changes and breakthroughs must guarantee sustainability in all areas of SEL.

The PRS and priorities of the sustainability, sustainable SD, EG, innovations and TBs can be described by the statements published in many fundamental scientific works (SWs), 
also in some previous works of the author of this article (Melnikas, 2013, 2018). The main theoretical attitudes and the basic ideas to initiate and conduct the SR, as well as to solve various PPs in different fields and aspects of sustainability, sustainable SD, EG, innovations and TBs are widely considered in many significant SWs (Collier, 2018; Haskel \& Westlake, 2018; Newnan, Eschenbach, \& Lavelle, 2017; Steger, 2013; Loy \& Aageson, 2018).

In particular, the contemporary understanding of sustainability, sustainable SD, EG, innovations and TBs must be based on modern approaches to social and economic systems (SESs), the structures of these systems, the evolution and changes of such structures and the formation of new structures (Buede, 2009; Melnikas, 2011).

It is obvious that the different SCs, ECs, TCs and DPs, particularly the processes of SD, EG, innovations, TP and TBs, are usually not fully balanced and insufficiently harmonized with each other. These circumstances lead to the fact that the real DPs and changes usually deviates from the trajectories that could be considered as adequate for the GS and standards of sustainability. It is also obvious that the main approaches and GS must be directly linked to the latest and newest challenges characteristic to the contemporary life of modern society.

It is also necessary to emphasize that the processes of innovations, of the SP and TP, of the EG, as well as various possibilities for activation and acceleration of these processes, must be examined and studied in the context of the CONCs of globalization, European integration (EI) and the creation of a knowledge-based society (KBS). SC and investigations in this area can also be considered as an important priority of the SR and practical activities.

Priority attention to the problems and processes of SD, EG, innovation activities, technological advance and TBs in the context of the challenges of globalization, EI and the creation of a KBS is reflected in many fundamental research works (RWs) (Castells, 2000, 2003, 2010; Mody, 2018; Collier, 2018; Harari, 2015, 2017; Hunt, 2000; Johnson \& Turner, 2010; Marshall, 2016; Neelankavil, 2007; Steger, 2013; Melnikas \& Reichelt, 2004). The ideas presented in these works can be considered as the basis for initiating and implementing new approaches (NAs) to the SSHs, as well as to successful solutions of the SCP and PPs related to the fundamental QCs in various areas of SEL. It is necessary to take into account various forecasts and insights that are oriented towards the long-term perspective (CIA und Dem National Intelligence Council, 2017).

In general, the key priorities of the $\mathrm{SD}, \mathrm{EG}$ and of the processes of the TP, innovations and the most important TBs can be identified and described in a variety of ways. Some approaches to these priorities are described in the author's previous publications (Melnikas, $2011,2013,2014,2018)$. A SR on these processes, as well as on the activation and acceleration of them includes a very wide range of topics and issues (Spetzler, Winter, \& Meyer, 2016). As a particularly important topics and issues, especially - under contemporary conditions (COCs) of globalization, EI, creation of KBS and knowledge economy (KE), could be noted the following:

- orientation to the solution of those problems of the society and its progress, which are most significant and particularly important to the contemporary societal development (Boldrin, Canova, Pischke, \& Puga, 2001; Calori, Atamer, \& Nunes, 2000; Chortareas \& Pelagidis, 2004; Currie, 2000; Garrett \& Mitchell, 2001; Grace \& Butler, 2005; Hayo \& Seifert, 2003; Huseman, Goodman, \& Rabinovitch, 1999, pp. 103-133; Krugman \& 
Obstfeld, 2002; Leydesdorff, 2004; Perraton, 2001; Rosenzweig, Gilbert, Malnight, \& Pucik, 2001; Steinmueller, 2002; Melnikas \& Reichelt, 2004; Melnikas, 2011, 2013);

- creation of conditions and assumptions, as well as preparation and use of effective tools and measures for the purposeful activation of SP and TP (Armstrong, 2006; David \& Foray, 2002; Ein-Dor, Myers, \& Raman, 2004; Hummels, Ishii, \& Yi, 2001).

In turn, the following can be specified as particularly significant social and economic problems of the CSO and its progress:

- problems of the availability of raw materials and energy resources, the natural raw materials and energy-saving problems, as well as the problems of efficient use of the natural raw materials and energy resources (these problems are particularly relevant in the European Union (EU) and in European economic area in general, because the European economy is exclusively dependent on conditions of the import of natural raw materials and energy resources);

- problems of the sustainable SD, ED and ECD and the problems of EG taking into account the adequacy of the processes of ED to the needs of social stability and high quality of life (these problems are particularly relevant in the context of the rise of social and economic differentiation (SED) in the contemporary world);

- the new problems of competition and competitiveness that arise in the context of contemporary globalization and economic internationalization (particularly significant are the problems caused by excessive differences in productivity, purchasing power and in the conditions of economic and business activities in different regions and countries);

- the problems, the essence of which is the increasing differences between the expectations and the opportunities to realize them in many areas of SEL (these problems create preconditions for conflicts and unsustainable development in many areas of SEL, in various sectors of economy and business and in many regions and countries).

It is clear that the solution of all these problems must be based, in particular, on the tools, measures and capabilities of the SP and TP: these tools, measures and capabilities must be orientated:

- to find and to implement various alternatives to the use of the limited raw materials and energy resources, to increase efficiency of the use of these materials and resources;

- to implement the OS, in particular - to achieve the needs of sustainable SD, ED and ECD (Olsen \& Osmundsen, 2003; Kim \& Shin, 2002; Bond, Syropoulos, \& Winters, 2001);

- to achieve a high level of competitiveness in all areas of economic activity, as well as to implement various ambitious standards of high quality, prosperity and social comfort (Hunt, 2000; Hofbauer, 2003; Melnikas \& Reichelt, 2004);

- to reduce various SEDs, to eliminate the preconditions of various conflicts and exclusions (Ghose, 2004; Göransson \& Söderberg, 2005).

The listed needs and aspirations to solve the described social (SOPs), economic problems (EPs) and other problems show and allow to highlight priorities of the creation of conditions and assumptions, as well as of the preparation and use of effective tools and measures for the purposeful activation of the processes of SD, EG and SP and TP. It goes without saying that such priorities reflect the prospects of the research on SP and TP, EG, as well as the prospects for the research on the sustainability and SD and ED in general. 
The listed needs and aspirations to solve the described SOPs, EPs and other problems can be identified as particularly significant under COCs of the EU: it can be said that a contemporary EU can be defined as a particularly important SES, which could be treated as a subject oriented towards solving the described problems.

It may be noted once again that the approaches to these problems and their solutions, presented in previous scientific works and publications, are insufficiently focused on the various circumstances and opportunities for promoting the creativity and the processes of the PC and CCs: priority orientation to the creativity and the processes of the PC and CCs in the general context of the needs to stimulate the processes of SD, EG and TBs, was not reflected in the author's previous works and publications (Melnikas, 2011, 2013, 2014, 2018).

It is obvious that creativity and purposeful promotion of CCs can be identified as a key condition and the most important prerequisite for successfully solving the all described problems. This statement is based on many fundamental SWs (Florida, 2012; Kačerauskas, 2012, 2014, 2015).

As is known, there are various concepts and approaches to creativity (Florida, 2012; Kačerauskas, 2012, 2014, 2015). In cases where the concept of creativity is associated with the solution of some actual problem, this concept can be described as the ability of a particular subject (individual, group, organization, other entity, community or society as a whole) to understand and solve the problem in a new, original, unconventional way (Melnikas, 2011, 2013). It goes without saying that this approach to the concept of creativity can also be applied where the concept of creativity is linked to solutions to the challenges of sustainable SD, EG, TBs.

The creativity and purposeful promotion of CCs can be identified also as a key condition and the most important prerequisite to ensure the sustainability and stability in many spheres of the SD, EG, TP and environmental changes in general. The creation, use and application of the managerial tools and instruments for the effective and purposeful PC and SUC and CCs should be understood as an IIP of the activities to achieve the GS and the needs of the sustainable SD, EG, TP and TBs.

This means that the most important problems and different circumstances of the creativity and purposeful promotion of CCs, as well as the key problems of the sustainable SD, EG, TP and TBs must be considered holistically: it can be emphasized that so-called $a$ holistic approach (HA) can be seen as a theoretical basis for the creation, use and application of the managerial tools and instruments to effectively promote and support the creativity and CCs, as well as to purposefully seek the GS and sustainable SD, EG, TP and TBs.

\section{Assumptions for implementation of the holistic approach to the creativity, creative changes, sustainable social development, economic growth and technological breakthroughs: the search for synergy}

It can be said that a HA to the creativity, CCs, sustainable SD, EG and TBs reflects the view that: a) the all most important processes of the SD and ED, EG, of the TP, innovations and of the TBs, as well as the processes of the PC and CCs should be defined as the processes that form an integral and indivisible whole (IIW); b) this IIW, as a system, has to be essentially sustainable.

In order that a HA would be implemented successfully, it is necessary to create two essential preconditions: a) the key priorities of the creativity and CCs, of the SD, EG and of the 
TP, innovations and the most important TBs should be reasonably determined, as well as the SES, which could be a subject to these priorities, should be clearly defined; b) a system of the appropriate managerial tools and instruments needed to creatively ensure the sustainability of the all processes of SD, EG and TP, as well as the proportionality of the SCs, ECs, TCs, ECCs and other changes, must be created, used and applied.

The needs to create these essential assumptions requires taking into account that the most important feature of the creativity and CCs is the creation of so-called a new quality (NQ). A creativity and the orientations to the CCs should be defined as an essential prerequisite and the key condition for the progress and innovative breakthroughs in any area of the SEL. In turn, the abilities of creativity and various possibilities to initiate and realize the CCs are always manifested in various and different forms of the creation of the NQ: the creation of a NQ, as well as the ability to achieve a NQ or a new qualitative level (NQL) always characterizes the result of creative activities and the potential of the creative activity itself (Melnikas, 2011, 2013, 2014, 2018).

So, obviously, the processes of the creation, use and application of the managerial tools and instruments to effectively promote and support the creativity and CCs must necessarily be related to the needs to create a NQ, as well as to achieve a NQ or a NQL. By the way, this statement can be regarded as valid in all cases where $a H A$ to the creativity, CCs, sustainable $\mathrm{SD}, \mathrm{EG}$ and TBs could and should be implemented.

A HA to the creativity, CCs, sustainable SD, EG and TBs always reflects the needs to take into account the most important priorities of various fundamental QCs in various areas of the SEL. Furthermore, it is clear that fundamental QCs always reflect and demonstrate the creation of a NQ or the abilities to achieve a NQ or a NQL. This leads to the conclusion that the processes of implementation and application of this HA can be based on the realization of the so-called universal principle of the creation of a "NQ". As it is stated in previous RWs and publications, universal principle of the creation of a "new quality" reflects the fundamental ideas of synergetics and of the processes of the search and use of synergetic effects (Melnikas, 2011, 2013, 2014, 2018).

Previous publications show, that the universal principle of the creation of a "new quality" can be seen as the most important principle to be applied in the scientific research, academic studies and practical activities. This principle shows that the new quality always develops by the amalgamation when elements of different origin that never had belonged to the same system collide. This principle expresses the idea of the developing and using the synergetic effects, and demonstrates that qualitative transformations always require actions and means necessary to join elements of different origin to the common system (Melnikas, 2011, 2013, 2014, 2018).

The principle of the creation of a "NQ" is very important in all cases when it comes to promoting creativity and CCs: a creative result always appears and manifests itself when different knowledge of different origin or various experiences of different nature are combined into a new whole and when a new system of knowledge and experiences is formed. Thus, this principle essentially expresses the nature of creativity and CCs.

This means that the essential purpose of the creation, use and application of the managerial tools and instruments to effectively promote and support the creativity and CCs is the creative search for synergy needed to solve various PRS in general, as well as to solve various problems of the sustainable SD, EG, TP and TBs. 
So, it goes without saying, that the managerial tools and instruments for the effective and purposeful PC and SUC and CCs can be created on the basis of the ideas set out.

It is important to note that there is a variety and diversity of different cases, possibilities and variants of connection, combining and joining (CCJ) and inclusion of the knowledge of different kinds and of the experiences of different nature and origin into the various commons and systems. The most important cases of such variety and diversity are as follows:

- CCJ of various and different cultures, mentalities, social models of different types, nature and origins;

- CCJ of various and different activities (VDAs) and DPs specific to different groups of society;

- CCJ of VDAs and DPs specific to different sectors and fields of economy, political, social life and TP;

- CCJ of VDAs and DPs specific to different countries, groups of countries or regional systems;

- CCJ of various and different fields and areas (VDFAs) of the SC and SR, as well as of (VDFAs) of academic studies and other academic activities;

- CCJ of (VDFAs) of the creative activities in various and different spheres (VDSs) of the art, culture, and creative industries;

- CCJ of (VDFAs) of the activities in VDSs of business;

- CCJ of various and different organizations and other formal and informal structures.

Obviously, in all such cases of the CCJ, a creative result is obtained.

So, the processes of the CCJ and inclusion of the knowledge of different kinds and of the experiences of different nature and origin into the various commons and systems could be defined as an essence and a basic prerequisite for the search and use of synergetic effects and for the creation of the qualitatively new products, structures and systems. The systems oriented and needed to the administration and support of such processes of the CCJ and inclusion can generally be understood as the appropriate managerial tools and instruments for the effective and purposeful PC and SUC and CCs.

In general, can be said that a HA to the creativity, CCs, sustainable SD, EG and TBs can be realized on the basis of the universal principle of the creation of a "NQ": orientation to search for synergy based on this principle allows for the proper creation, development and use of relevant managerial tools and instruments for the effective and purposeful PC and SUC and CCs.

\section{Conclusions}

The conducted TR makes it possible to formulate some substantive conclusions and recommendations:

1. The SR and practical activities aimed at solving the problems of creativity (PCR), CCs, of the sustainable SD, EG, innovations and TBs should be regarded as exceptionally important and significant. A key priority for such research and activities is to seek and ensure that the changes and DPs of different origins could be effectively coordinated, balanced and harmonized. This priority arises and becomes very important: in the real practice of the SEL, it is very often the case that various innovations and TBs at the same time not only stimulate EG, but also create preconditions for various unfair development circumstances. Also, in the real practice of the SEL, it is very often the case 
that various processes of EG at the same time not only stimulate the $\mathrm{SD}$, but also create preconditions for various disproportions and conflicts. This means that the processes of the SD, EG, innovations and TBs need to be seen not only as an important positive factor for the SD and ED in general, but also as a circumstance that can have negative consequences in terms of sustainability. These statements allow to adequately perceive the topicalities and needs of the contemporary GS and ideas of sustainability, as well as the problems of harmonization of the processes (HPs) of SD, EG, innovations and TBs. These statements also show the needs for a new understanding of the role and importance of creativity and CCs. These statements also reflect the needs to implement a HA to the processes of the PC and CCs, sustainable SD, EG and TBs, as a whole;

2. The PCR, of the promotion of the CCs, as well as the PRS and of HPs of SD, EG, innovations and TBs are particularly relevant under COCs of the processes of globalization, of the KBS and KE creation and EI: the qualitatively new challenges and needs become apparent under these conditions. For this reason, a NAs have to be applied to solving the PCR, sustainability and of HPs of SD, EG, innovations and TBs. An original approach, that is focused on the use of the managerial tools and instruments for the effective and purposeful PC and SUC and CCs management tools and instruments can be identified as an approach that is particularly promising;

3. A HA to the creativity, CCs, sustainable SD, EG and TBs always reflects the needs to take into account the most important priorities of various fundamental QCs in various areas of the SEL. The processes of implementation and application of this HA can be based on the realization of the universal principle of the creation of a "NQ": this principle reflects the fundamental ideas of synergetics and of the processes of the search and use of synergetic effects;

4. Further research oriented to the complex SC and exploration of the processes and phenomena of the development of creativity, as well as of the promotion and acceleration of the processes of CCs, sustainable SD, EG, innovations and TBs, are of particular importance, especially in the context of the aspirations of the needs and challenges of the KBS creation. It is particularly noteworthy that the proposed and outlined theoretical approach can be successfully applied in the future by various empirical studies of the relevant profile.

\section{References}

Armstrong, M. (2006). A handbook of human resource management practice. London and Philadelphia: Kogan Page.

Boldrin, M., Canova, F., Pischke, J.-S., \& Puga, D. (2001). Inequality and convergence in Europe's regions: reconsidering European regional policies, Economic Policy, 16(32), 205+207-253. https://doi.org/10.1111/1468-0327.00074

Bond, E. W., Syropoulos, C., \& Winters, L. A. (2001). Deepening of regional integration and multilateral trade agreements. Journal of International Economics, 53(2), 335-361. https://doi.org/10.1016/S0022-1996(00)00064-7

Buede, D. M. (2009). The engineering design of systems: models and methods. Series: Wiley Series in Systems Engineering and Management. Sage, A. P. (Series Ed.). Hoboken, NJ: John Wiley and Sons, Inc. https://doi.org/10.1002/9780470413791 
Calori, R., Atamer, T., \& Nunes, P. (2000). The dynamics of international competition: from practice to theory. Series: Sage Strategy Series. London: SAGE Publications. https://doi.org/10.4135/9781446280232

Castells, M. (2000). The information age: economy, society and culture. Vol. I: The Rise of the Network Society. Oxford: Blackwell Publishers Ltd.

Castells, M. (2003). The information age: economy, society and culture. Vol. II: The Power of Identity. Oxford: Blackwell Publishers Ltd.

Castells, M. (2010). The information age: economy, society and culture. Vol. III: End of Millennium. Oxford: Blackwell Publishers Ltd.

Chortareas, G. E., \& Pelagidis, Th. (2004). Trade flows: a facet of regionalism or globalisation? Cambridge Journal of Economics, 28(2), 253-271. https://doi.org/10.1093/cje/28.2.253

CIA und Dem National Intelligence Council. (2017). Die Welt im Jahr 2035. Gesehen von der CIA. Das Paradox des Fortschritts. Muenchen: C.H. Beck Verlag.

Collier, P. (2018). The future of capitalism: facing the new anxieties. New York, NY: HarperCollins Publishers.

Currie, W. (2000). The global information society. Series: Wiley Series in Information Systems. Chichester: John Wiley \& Sons, Ltd.

David, P. A., \& Foray, D. (2002). An introduction to the economy of the knowledge society. International Social Science Journal, 54(171), 9-23. https://doi.org/10.1111/1468-2451.00355

Ein-Dor, Ph., Myers, M., \& Raman, K. S. (2004). IT industry development and the knowledge economy: a four country study. Journal of Global Information Management, 12(4), 23-49. https://doi.org/10.4018/jgim.2004100102

Florida, R. (2012). The rise of the creative class (revisited). New York: Basic Books.

Garrett, G., \& Mitchell, D. (2001). Globalization, government spending and taxation in the OECD. European Journal of Political Research, 39(2), 145-177. https://doi.org/10.1111/1475-6765.00573

Ghose, A. K. (2004). Global inequality and international trade. Cambridge Journal of Economics, 28(2), 229-252. https://doi.org/10.1093/cje/28.2.229

Göransson, B., \& Söderberg, J. (2005). Long waves and information technologies - on the transition towards the information society. Technovation, 25(3), 203-211.

https://doi.org/10.1016/S0166-4972(03)00115-9

Grace, A., \& Butler, T. (2005). Beyond knowledge management: introducing learning management systems. Journal of Cases on Information Technology, 7(1), 53-70. https://doi.org/10.4018/jcit.2005010104

Harari, Y. N. (2017). Homo deus: a brief history of tomorrow. New York, NY: HarperCollins Publishers. https://doi.org/10.17104/9783406704024

Harari, Y. N. (2015). Sapiens: a brief history of humankind. New York, NY: HarperCollins Publishers.

Haskel, J., \& Westlake, S. (2018). Capitalism without capital: the rise of the intangible economy. Oxford: Princeton University Press. https://doi.org/10.1515/9781400888320

Hayo, B., \& Seifert, W. (2003). Subjective economic well-being in Eastern Europe. Journal of Economic Psychology, 24(3), 329-348. https://doi.org/10.1016/S0167-4870(02)00173-3

Hofbauer, H. (2003). Ost Erweiterung: Vom Drang nach Osten zur peripheren EU-Integration. Wien: Promedia.

Hummels, D., Ishii, J., \& Yi, K.-M. (2001). The nature and growth of vertical specialization in world trade. Journal of International Economics, 54(1), 75-96.

https://doi.org/10.1016/S0022-1996(00)00093-3

Hunt, Sh. D. (2000). A general theory of competition: resources, competences, productivity, economic growth. Series: Marketing for a New Century. Malhotra, N. K. (Series Ed.). Thousand Oaks: Sage Publications, Inc. 
Huseman, R. C., Goodman, J. P., \& Rabinovitch, D. (1999). Leading with knowledge: the nature of competition in the 21st century. Thousand Oaks: SAGE Publications, Inc. https://doi.org/10.4135/9781452220673

Johnson, D., \& Turner, C. (2010). International business: themes and issues in the modern global economy. New York, NY: Routledge. https://doi.org/10.4324/9780203861615

Kačerauskas, T. (2012). Creative economy and technologies: social, legal and communicative issues. Journal of Business Economics and Management, 13(1), 71-80. https://doi.org/10.3846/16111699.2011.620151

Kačerauskas, T. (2014). Kūrybos visuomenè. Vilnius: Vilniaus Gedimino technikos universiteto leidykla „Technika“. https://doi.org/10.3846/2265-M

Kačerauskas, T. (2015). Technologies in creative economy and creative society. Technological and Economic Development of Economy, 21(6), 855-868. https://doi.org/10.3846/20294913.2015.1036325

Kim, S., \& Shin, E.-H. (2002). A longitudinal analysis of globalization and regionalization in international trade: a social network approach. Social Forces, 81(2), 445-471. https://doi.org/10.1353/sof.2003.0014

Krugman, P. R., \& Obstfeld, M. (2002). International economics: theory and policy. Amsterdam: Addison Wesley.

Leydesdorff, L. (2004). The university-industry knowledge relationship: analyzing patents and the science base of technologies. Journal of the American Society for Information Science and Technology Banner, 55(11), 991-1001. https://doi.org/10.1002/asi.20045

Loy, A., \& Aageson, T. (2018). Creative economy entrepreneurs: from startup to success. How entrepreuners in the creative industries are transforming the global economy. Santa Fe, NM: Global Center for Cultural Entrepreneurship DBA, Creative Startups.

Marshall, T. (2016). Geografijos įkaitai: dešimt žemèlapiu, pasakančiu viską, kas lemia pasaulio politiką. Vilnius: Tyto alba.

Melnikas, B. (2014). Tarptautinis verslas: inovacijos ir žiniu ekonomikos kūrimas. Vilnius: Vilniaus Gedimino technikos universiteto leidykla „Technika“. https://doi.org/10.3846/1484-S

Melnikas, B. (2018). The knowledge economy and the activation of scientific and technological progress: contemporary challenges. Ekonomika, 97(1), 7-23. https://doi.org/10.15388/Ekon.2018.1.11775

Melnikas, B. (2011). Transformacijų visuomené: ekonomika, kultūra, inovacijos, internacionalizavimo procesai. Vilnius: Vilniaus Gedimino technikos universiteto leidykla „Technika“. https://doi.org/10.3846/1906-M

Melnikas, B. (2013). Žiniomis grindžiamos visuomenès kūrimas: globalizacija, darni plètra, ekonominiai sprendimai. Vilnius: Vilniaus universiteto leidykla.

Melnikas, B., \& Reichelt, B. (2004). Wirtschaft und Mentalitaet: Tendenzen der EU-Osterweiterung. Leipzig: Leifim - Verlag.

Mody, A. 2018. Euro tragedy: a drama in nine acts. Oxford: Oxford University Press. https://doi.org/10.1093/oso/9780199351381.001.0001

Neelankavil, J. P. (2007). International business research. New York, London: M.E.Sharpe.

Newnan, D. G., Eschenbach, T. G., \& Lavelle, J. P. (2017). Engineering economic analysis. Oxford: Oxford University Press.

Olsen, T. E., \& Osmundsen, P. (2003). Spillovers and international competition for investments. Journal of International Economics, 59(1), 211-238. https://doi.org/10.1016/S0022-1996(02)00086-7

Perraton, J. (2001). The global economy - myths and realities. Cambridge Journal of Economics, 25(5), 669-684. https://doi.org/10.1093/cje/25.5.669

Rosenzweig, Ph., Gilbert, X., Malnight, Th., \& Pucik, V. (2001). Accelerating international growth. Series: Executive Development from IMD. Chichester: John Wiley \& Sons, Ltd. 
Spetzler, C., Winter, H., \& Meyer, J. (2016). Decision quality: value creation from better business decisions. Hoboken, NJ: John Wiley and Sons, Inc. https://doi.org/10.1002/9781119176657

Steger, M. B. (2013). Globalization: a very short introduction. Gosport: Ashford Colour Press, Ltd. https://doi.org/10.1093/actrade/9780199662661.001.0001

Steinmueller, W. E. (2002). Knowledge-based economies and information and communication technologies. International Social Science Journal, 54(171), 141-153.

https://doi.org/10.1111/1468-2451.00365

\title{
DARNI SOCIALINĖ RAIDA, EKONOMIKOS AUGIMAS IR TECHNOLOGINIAI PROVERŽIAI: KÜRYBIŠKUMAS IR KÜRYBIŠKI POKYČIAI
}

\author{
Borisas MELNIKAS
}

\begin{abstract}
Santrauka
Šis teorinio pobūdžio straipsnis skirtas kūrybiškumo ir kūrybiškų pokyčių, taip pat darnios socialinès raidos, ekonomikos augimo bei technologinių proveržių, procesų ir reiškinių, būdingų svarbiausioms šiuolaikinio socialinio ir ekonominio gyvenimo sritims, kompleksinei analizei ir skatinimui.

Straipsnio tikslas - parengti, paskleisti ir igyvendinti naują darnios socialinės raidos, ekonomikos augimo, inovacijų ir technologinių proveržių koncepciją, kurios esmé - integruotas holistinis požiūris ị ịvairių raidos procesų suderinimą bei adekvačių valdymo priemonių, grindžiamų kūrybiškumo ir kūrybiškų pokyčių idejjomis, naudojimą.

Straipsnio tyrimo metodika - sisteminè ịvairių mokslinių idèjų ir požiūrių analizė bei sintezè, naujų įžvalgų formulavimas ir pritaikymas.

Straipsnio išvados - parengta nauja kūrybiškumo ir kūrybiškų pokyčių analizès bei skatinimo koncepcija. Ji atspindi integruotą požiūrị ị socialinès raidos, ekonomikos augimo, inovacinès veiklos, technologijų pažangos ir proveržių problemų sprendimą, taip pat ị specifinių vadybos priemonių, grindžiamų kūrybiškumo ir kūrybiškų pokyčių idejjomis, naudojimą. Igyvendinant šią koncepciją socialinės ir ekonominės raidos, mokslinių tyrimų ir akademinių studijų praktikoje, sudaromos prielaidos numatyti ir realizuoti naujas galimybes plètoti socialinę ir ekonominę pažangą, aktyvinti ekonomikos augimą ir technologinius proveržius šiuolaikinemis globalizacijos, Europos integracijos ir žinių visuomenès kūrimo sąlygomis.

Straipsnio tyrimu apribojimai - siūlomos koncepcijos pritaikymas apsiriboja bendrųjų visuomenès raidos procesų ir tendencijų tyrimų, taip pat makroekonominès analizès ir strateginių sprendimų, skirtų socialinei, ekonominei, politinei ir technologinei plètrai, rengimo atvejais.

Straipsnio originalumas / verte - aprašomos ir išanalizuotos naujos įžvalgos bei perspektyvios idejjos, naudotinos plètojant ịvairias socialinių ir humanitarinių mokslų kryptis, ypač sociologiją, ekonomiką ir vadybą, taip pat reikšmingus valdymo priemonių taikymo tyrimus. Orientacija ị šias įžvalgas ir idejas leidžia išryškinti naujus mokslinių tyrimų prioritetus ir perspektyvias tendencijas.
\end{abstract}

Reikšminiai žodžiai: kūrybiškumas, ekonomikos augimas, inovacijos, vadyba, moksliniai tyrimai, socialinè raida, tvarumas, technologijų pažanga ir proveržiai. 